\author{
I.S. Kostiv, R.I. Havryliv
}

\title{
DETERMINATION OF OPTIMAL CONDITIONS FOR PREPARATION OF 2-HYDROXYETHYL-1,3,4-TRIMETHYLCYCLOHEX-3-ENCARBOXYLATE
}

\author{
Lviv Polytechnic National University, Lviv, Ukraine
}

\begin{abstract}
2-Hydroxyethyl-1,3,4-trimethylcyclohex-3-encarboxylate (HTMC) was synthesized by the reaction of Diels-Alder. The influence of temperature and molar ratio of reagents on the yield of the end product was investigated. The kinetics of the cycloaddition reaction between 2,3-dimethylbuta-1,3-diene (DMB) and 2-hydroxyethylmethacrylate (HEMA) was studied. The reaction rate constants and the activation parameters of the reaction were determined. It was stated that the yield of HTMC increases from $76 \%$ to $87 \%$ when the temperature increases from $403 \mathrm{~K}$ to $433 \mathrm{~K}$, respectively. With a further increase in the temperature, DMB boils and HEMA remains in a liquid state, therefore, the yield of the end product does not increase appreciably. An increase in the excess of DMB:HEMA from $1: 1$ to $2.5: 1$ allows increasing the yield of HTMC from $83 \%$ to $87 \%$. The optimal conditions for the HTMC production have been determined as follows: the temperature of $433 \mathrm{~K}$ and the molar ratio of reagents DMB:HEMA=1.5:1; the yield of HTMC reaches $87 \%$ at the output of $104 \mathrm{~g} /(\mathrm{l} \cdot \mathrm{h})$ under these conditions. On the basis of the obtained reaction rate constants and the activation parameters of the $[4+2]$-cyclic addition of 2,3-dimethylbuta-1,3-diene and 2-hydroxyethylmethacrylate, we found out that the reaction under study obeys the second-order kinetic equation. The kinetic data indicated the synchronous cyclization process. The acceleration of the reaction with an increase in the depth of the process can be explained by matrix or cellular effects.
\end{abstract}

Keywords: 2,3-dimethylbutadiene, 2-hydroxyethylmethacrylate, 2-hydroxyethyl-1,3,4trimethylcyclohex-3-encarboxylate, cycloaddition reaction, cyclohexencarboxylates.

DOI: $10.32434 / 0321-4095-2019-125-4-73-79$

\section{Introduction}

Alkylcyclohexenecarboxylates are important substances which can be used as monomers in production of new polymeric materials, plasticizers of concrete and concrete mixtures with improved properties [1]. They can also be used as antibiotics, drugs that inhibit biosynthesis of cholesterol and significantly reduce its level in blood, anticonvulsant drugs [2], food flavorings, taste food components, perfume compositions and cosmetics [3], plant growth activators, modifiers of epoxy resins, plasticizers and comonomers. Alkylcyclohexenecarboxylates are increasingly being used as a basis for synthesis of polyfunctional polymers of diverse structures with predefined physical-chemical characteristics [4].

Polymerization of alkylcyclohexenecarboxylates allows preparation of optical lenses. Optically-active liquid crystals are used as a component of liquid crystals composition for electrooptical devices due to their dielectric anisotropy properties [5]. Alkylcyclohexene derivatives are also attractive since the presence of homologous series permits synthesizing secondary and tertiary hydroaromatic alcohols and hydroaromatic hydrocarbons [6].

The aim of this work was to prepare new monomers, unsaturated esters of alkylsubstutited cyclohexenecarboxylic acids. We used the reaction of [4+2]-cycloaddition between 2,3-dimethylbuta1,3-diene (DMB) and 2-hydroxyethylmethacrylate (HEMA) to synthesize 2-hydroxyethyl-1,3,4trimethylcyclo-hex-3-encarboxylate (HTMC) (Scheme 1).

The kinetics of the preparation of 2-hydroxyethyl-1,3,4-trimethylcyclohex-3-encarboxylate was investigated and the optimal conditions for the synthesis by Diels-Alder reaction were determined. 
<smiles>CC1=C(C)CC(C)(C(=O)OCCO)CC1</smiles>

Scheme 1. 2-Hydroxyethyl-1,3,4-trimethylcyclohex-3encarboxylate

\section{Experimental}

\section{Materials}

Earlier [7], we synthesized 2-hydroxyethyl1,3,4-trimethylcyclohex-3-encarboxylate (HTMC) using HEMA and DMB. The synthesis DMB was characterized elsewhere [8]. The synthesis was carried out according to the method described in work [9] (Scheme 2).<smiles>C=C(C)C(=C)[CH+]C=C(C)C(=O)OCCO</smiles><smiles>CC1=C(C)CC(C)(C(=O)OCCO)CC1</smiles>

Scheme 2. [4+2]-Cycloaddition between 2,3dimethylbutadiene and 2-hydroxyethylmethacrylate

\section{Methods}

Kinetic study was performed by means of a laboratory facility. The installation consists of a glass filling with silicone oil, a heating system, magnetic stirrer and stand with ampoules. A glass with silicone oil and a magnet was placed on a magnetic stirrer. Then, a silicone oil spiral with length of $280 \mathrm{~mm}$ was sealed in a glass tube and placed into a liquid. The spiral was connected to the transformer and automatic temperature controller to ensure and maintain the temperature throughout the process. Hermetically sealed ampoules with reagents, previously fixed in a stand for ampoules, were placed in a glass with silicone oil heated to a temperature of 393-443 K. The ampoules were immersed so that they were almost completely in silicone oil, thus providing uniform heating of the mixture.

Kinetic study was conducted in temperature controlled vacuum-sealed glass ampoules accordingly to the procedure described elsewhere [10]. The temperatures were in the range of 403-433 K. HEMA and DMB at a molar ratio of 1:1.5 were loaded into the ampoules $\left(10 \mathrm{~cm}^{3}\right)$ and then hydroquinone was added (1\%). The ampoules were sealed, placed into a thermostat and heated for 2 hours. The ampoules were successively removed from the thermostat, quickly cooled and opened every $15 \mathrm{~min}$ from the beginning of the heating.

The reaction mixture was analyzed by a gasliquid chromatography device SELMI CHROM-1 using computer registration with a DTP thermal conduction detector and a chromatograph column of $1 \mathrm{~m}$ in length and diameter of $3 \mathrm{~mm}$ filled with polisorb-1. The detector current was $37 \mathrm{~mA}$. The temperatures of the column, detector and evaporator were $393 \mathrm{~K}, 423 \mathrm{~K}$ and $423 \mathrm{~K}$, respectively. Hydrogen was a gas-carrier with a consumption of $22 \mathrm{ml} \cdot \mathrm{min}^{-1}$, the sample volume was $1 \mathrm{ml}$. Internal normalization method was used to record a signal and perform quantitative chromatographic analysis. The error of chromatographic analysis determined from several parallel measurements did not exceed 3\% [11].

\section{Synthesis of HTMC}

$121.5 \mathrm{ml}$ HEMA and hydroquinone (1\%) was added to the solution of $169.5 \mathrm{ml} \mathrm{DMB}$. The reaction mixture was loaded into the ampoules $\left(30 \mathrm{~cm}^{3}\right)$ and heated for 7 hours at the temperature of $433 \mathrm{~K}$. The separation of the reaction mixture was carried out in two stages. Firsty, the distillation of the reaction mixture was performed at atmospheric pressure in a flask equipped with a reflux condenser with a length of $20 \mathrm{~cm}$. After reaching the maximum cube temperature of $345 \mathrm{~K}$, the remains of the original DMB were separated. Then, having reached the temperature of $395 \mathrm{~K}$, the distillation was carried out under vacuum (4 $\mathrm{gPa})$. The HTMC was separated at the temperature of $379 \mathrm{~K}$. The yield of HTMC was $87 \%$. These values of HTMC yield are in good agreement with the data received from mathematical modeling of the process [7].

\section{Results and discussion}

To determine the optimal conditions of cycloaddition between DMB and HEMA that provide maximum HTMC yield, the effects of temperature and reactants molar ratio on the yield of the end product were studied. To determine the effect of molar ratio, the experiments were conducted at $433 \mathrm{~K}$ and molar ratio of DMB:HEMA of $1: 1$, $1.25: 1,1.5: 1,1.75: 1$ and 2.5:1. The HTMC yield increased from $83 \%$ to $87 \%$ with increasing the DMB:HEMA excess from $1: 1$ to $1.5: 1$. A further increase in DMB excess did not cause an essential increase in the HTMC yield. In addition, the large DMB excess is not profitable. The influence of DMB:HEMA molar ratio on HTMC yield is shown in Figure 1. 


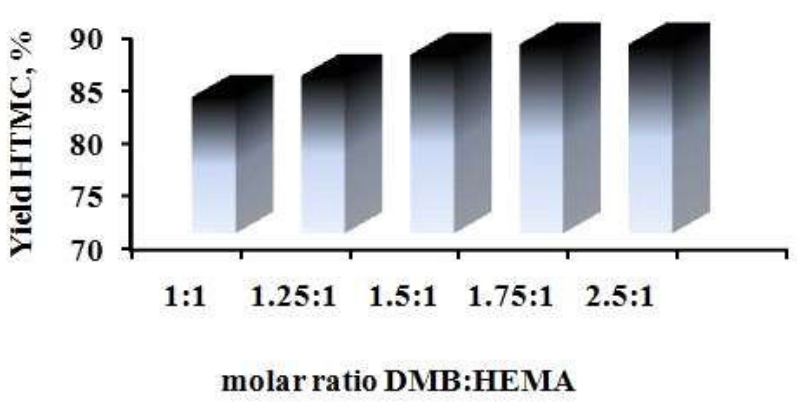

Fig. 1. The influence of the DMB:HEMA molar ratio on the HTMC yield at $433 \mathrm{~K}$

The optimum molar ratio of DMB:HEMA was stated to be $1.5: 1$, because the following changes did not appreciably increase the product yield. To determine the effect of temperature on the cycloaddition between DMB and HEMA, the experiments were conducted in the temperature range of $403-443 \mathrm{~K}$ and at the molar ratio of DMB:HEMA=1.5:1. The HTMC yield increased from $76 \%$ to $87 \%$ with an increase in the temperature from 403 to $433 \mathrm{~K}$. An increase in the HTMC yield was not observed with a further increase in the temperature. The effect of temperature on HTMC yield is demonstrated in Figure 2.

The optimal temperature was accepted to be $433 \mathrm{~K}$, because this value provides the highest yield of HTMC.

The kinetics of the reaction under consideration

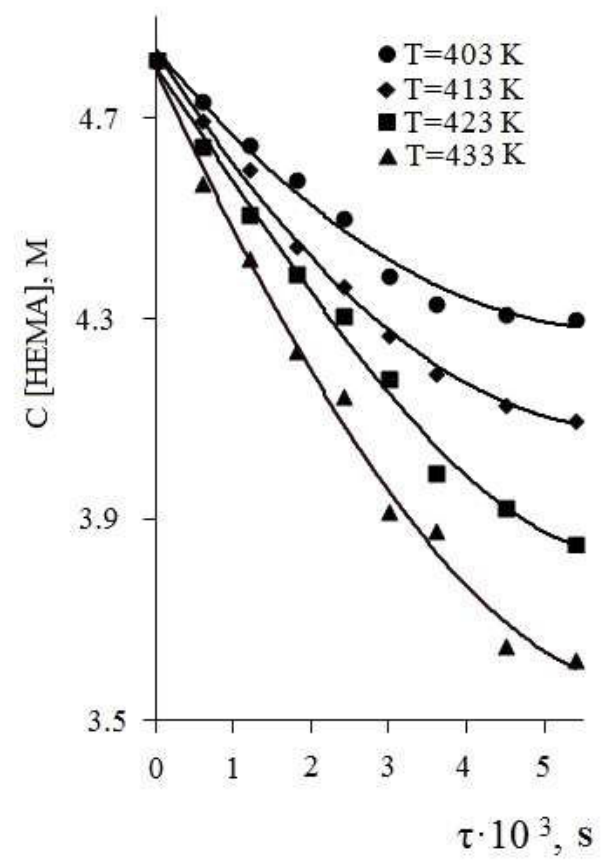

$\mathbf{a}$

Fig. 3. Kinetic curves of HEMA consumption (a) and HTMC accumulation (b) at the molar ratio DMB:HEMA= 1.5:1 in the

temperature range of $430-433 \mathrm{~K}$

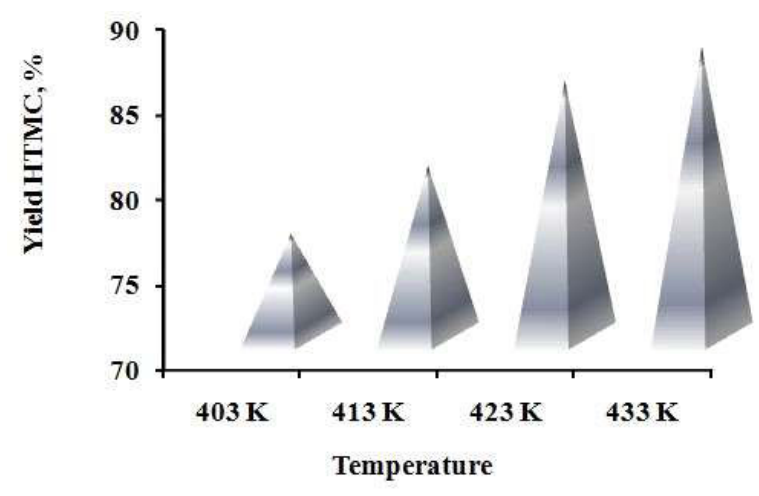

Fig. 2. The effect of temperature on the HTMC yield at the molar ratio of DMB:HEMA of 1.5:1

was studied at the optimal values of DMB:HEMA molar ratio in the temperature range of 403-433 K.

The kinetic curves of HEMA consumption and HTMC accumulation are shown in Fig. 3,a,b. The interaction between HEMA and DMB at the molar ratio HEMA:DMB $=1.5: 1$ in the initial sections of the kinetic curves (Figures 3,a) is well described by the second-order kinetic equation for the irreversible reactions. Also, these results are in agreement with literature data, in particular with those concerning the interaction between diethylazodicarboxylate and unsaturated fatty acids [12]. To treat our experimental data, we also used the method of the least squares for the dependence in coordinates of

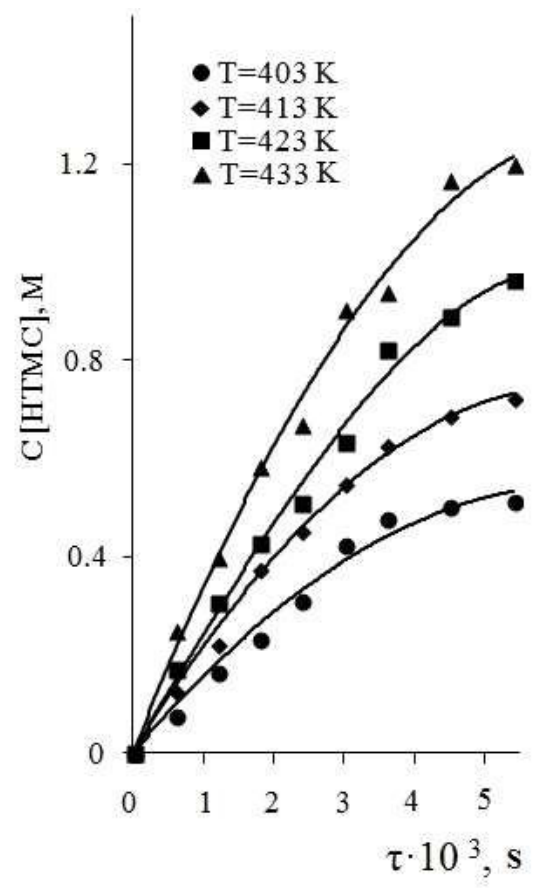

b 
$\left(1 /\left[\mathrm{C}_{1}\right]_{0}\left[\mathrm{C}_{2}\right]_{0}\right) \cdot \ln \left(\left[\mathrm{C}_{1}\right]_{\mathrm{t}} \cdot\left[\mathrm{C}_{2}\right]_{0} /\left[\mathrm{C}_{1}\right]_{0} \cdot\left[\mathrm{C}_{2}\right]_{\mathrm{t}}\right)=\mathrm{kt}$ for the second-order reaction with a non-equivalent ratio of reactants [13]. The reaction rate constants were determined by the slope of the linearized kinetic curves (Table 1).

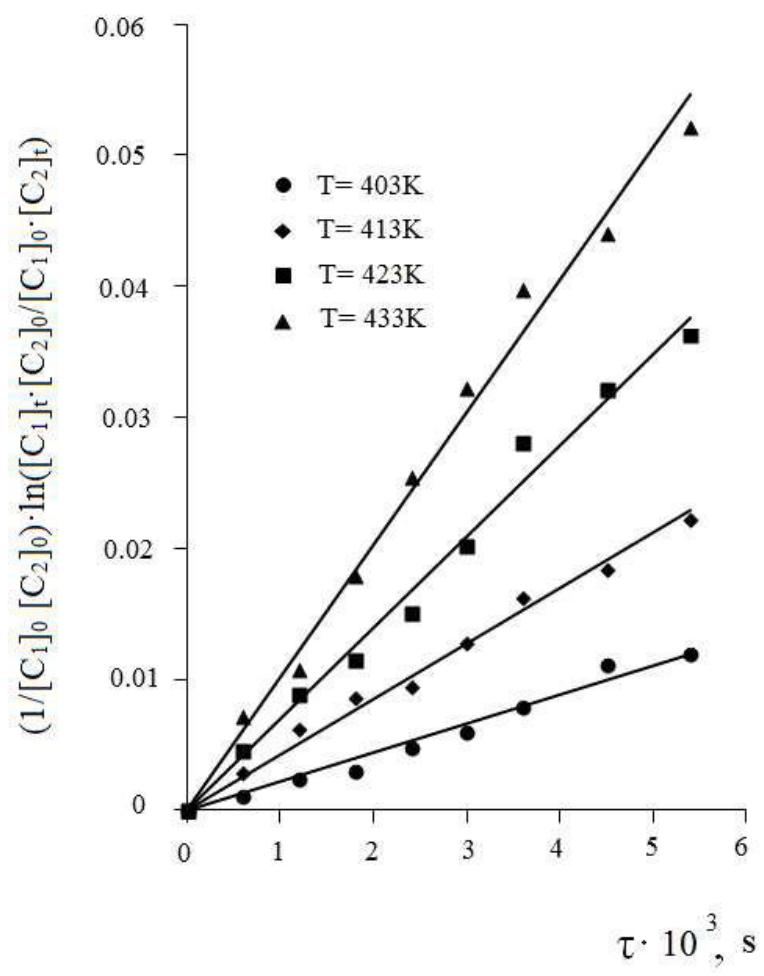

Fig. 4. Linearized kinetic curves for the HEMA consumption in the temperature range of $403-433 \mathrm{~K}$ at the molar ratio DMB:HEMA $=1.5: 1$

Table 1

Dependence of the rate constants of cyclization between DMB and HEMA on the temperature at the molar ratio DMB:HEMA=1.5:1

\begin{tabular}{c|c|c|c}
\hline $\begin{array}{c}\text { Temperature, } \\
\mathrm{K}\end{array}$ & $\begin{array}{c}(\mathrm{k} \pm \Delta \mathrm{k}) \cdot 10^{6}, \\
1 /(\mathrm{mol} \cdot \mathrm{s})\end{array}$ & $\Delta \mathrm{k}, \%$ & $\begin{array}{c}\text { HEMA, } \\
\text { conversion, \% }\end{array}$ \\
\hline 403 & $2.2 \pm 0.1$ & 4.2 & 11.1 \\
\hline 413 & $4.2 \pm 0.2$ & 4.6 & 17.2 \\
\hline 423 & $6.9 \pm 0.3$ & 4.8 & 24.9 \\
\hline 433 & $10.1 \pm 0.4$ & 4.3 & 28.4 \\
\hline
\end{tabular}

As can be seen from Table 1, the value of the rate constant increases with an increase in temperature. The temperature dependence of rate constant is described by the Arrhenius equation (Fig. 5). The correlation coefficient is $\mathrm{R}^{2} \approx 0.96$.

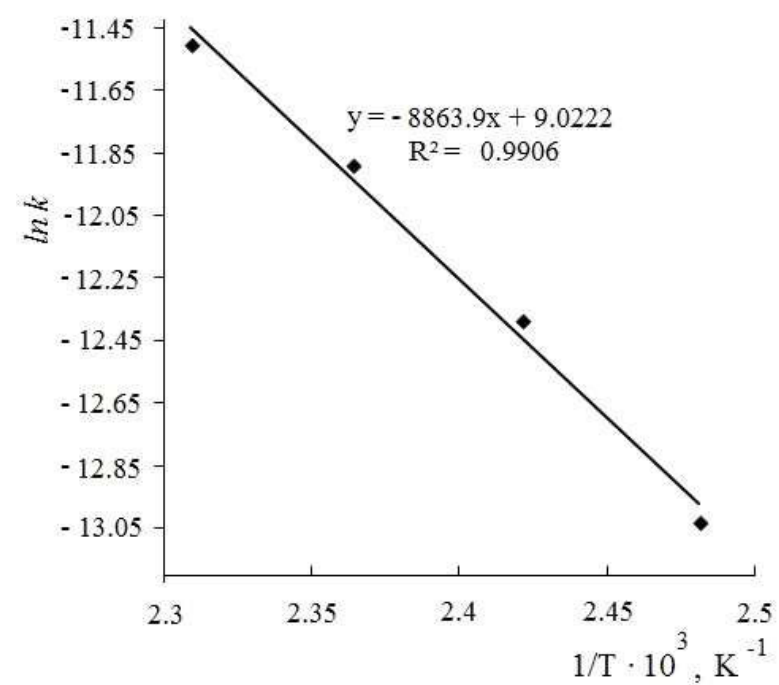

Fig. 5. Arrhenius dependence for the cycloaddition reaction between DMB and HEMA

The activation energy was calculated from the presented dependence. The thermodynamics parameters of the activating state (enthalpy of activation, $\Delta \mathrm{H}^{\#}$, and entropy of activation, $\Delta \mathrm{S}^{\#}$ ) were evaluated accordingly to the Eyring equation [13] (Table 2).

Table 2

Activation parameters of the cyclization between DMB and HEMA

\begin{tabular}{c|c}
\hline Parameter & Value \\
\hline $\mathrm{E}^{\#} \pm \Delta \mathrm{E}^{\#}, \mathrm{~kJ} / \mathrm{mol}$ & $73.7 \pm 7.2$ \\
\hline$\Delta \mathrm{H}^{\#}, \mathrm{~kJ} / \mathrm{mol}$ & 62 \\
\hline$\Delta \mathrm{S}^{\#}, \mathrm{~J} / \mathrm{mol} \cdot \mathrm{K}$ & -181 \\
\hline $\operatorname{lgA}$ & 9.02 \\
\hline $\mathrm{A}, \mathrm{l} /(\mathrm{mol} \cdot \mathrm{s})$ & $1.04 \cdot 10^{10}$ \\
\hline
\end{tabular}

The value of activation energy $E_{\text {act }}=73.7 \mathrm{~kJ} / \mathrm{mol}$ shows that the process is not controlled by the diffusion control under experimental conditions but occurs in the kinetic regime in the initial step of the reaction [13]. A high negative value of activation entropy $(181 \mathrm{~J} /(\mathrm{mol} \cdot \mathrm{K}))$ and a value of activation enthalpy, which is equal to $62 \mathrm{~kJ} / \mathrm{mol}$, are typical of Diels-Alder reactions [13]. Opening and formation of bonds in these reactions occur synchronously, and energy consumption for one bond opening in the transitional state is compensated by the energy of another bond formation [13]. It means that the investigated reaction is energetically favorable.

The investigated reaction obeys the secondorder kinetic law which is confirmed by obtained rate constants and activation parameters of 
The material balance of the synthesis of HTMC under optimal conditions (temperature $433 \mathrm{~K}$, molar ratio DMB:HEMA=1.5:1, duration $7 \mathrm{~h}, \mathrm{Q}=104 \mathrm{~g} /(\mathrm{lYh})$

\begin{tabular}{|c|c|c|c|c|c|c|c|}
\hline \multicolumn{4}{|c|}{ Loaded } & \multicolumn{4}{|c|}{ Obtained } \\
\hline Substance & $\mathrm{g}$ & $\mathrm{mol}$ & Yield, $\%$ & Substance & $\mathrm{g}$ & $\mathrm{mol}$ & Yield, $\%$ \\
\hline 1. DMB & 123.00 & 1.50 & \multirow{5}{*}{-} & 1. HTMC & 184.70 & 0.87 & 87 \\
\hline 2. HEMA & 130.00 & 1.00 & & 2 DMB (non-reacted) & 51.10 & 0.63 & \multirow{4}{*}{ - } \\
\hline \multirow{3}{*}{ Total } & \multirow{3}{*}{253.00} & \multirow{3}{*}{-} & & 3. HEMA (non-reacted) & 16.90 & 0.16 & \\
\hline & & & & 4. Azeotrope (losses) & 0.30 & - & \\
\hline & & & & Total & 253.00 & - & \\
\hline
\end{tabular}

Note: HTMC was characterized by IR, ${ }^{1} \mathrm{H}$ NMR, and ${ }^{13} \mathrm{C}$ NMR spectra.

cycloaddition between DMB and HEMA. It is also confirmed by the linearized kinetic curves (Fig. 4).

However, the reaction occurs at $433 \mathrm{~K}$ in a hermetically sealed system. Therefore, the pressure will increase. That is why, further, the reaction rate will no longer proceed in the kinetic regime. The Arrhenius equation may take into account the change in the reaction rate only for the initial step of the reaction. With increasing pressure, the physical properties of the reaction medium will be changed and the reaction will occur under the diffusion control of the kinetics. In addition, this reaction occurs at a non-equimolar ratio of reagents. The excess of DMB contributes to a stable reaction rate owing to stronger interactions between reagent molecules. All of these factors have a significant effect on the course of the reaction and especially on its duration.

Under the chosen optimal conditions, HTMC synthesis was performed and some physicochemical characteristics were determined (Table 3). Synthesized HTMC has the following physicochemical characteristics: $\mathrm{T}_{\text {boil }}=379 \mathrm{~K}$ at $4 \mathrm{gPa}$; $\mathrm{n}^{20}{ }_{\mathrm{D}}=1.4861 ; \mathrm{d}^{20}{ }_{4}=1.0582$; MR found 53.8; calc. 53.4.

IR spectra of HTMC reveal characteristic absorption bands corresponding to the functional groups presented in the molecule: two bands in the range of $1710-1730$ and $1730-1750 \mathrm{~cm}^{-1}$ belonging to the ester group; the bands in the range of 16201680 and $1500-1520 \mathrm{~cm}^{-1}$ belonging to the aromatic ring and three bands in the range of 2890-2920, 2925-2950 and $2870-2910 \mathrm{~cm}^{-1}$ corresponding to the methyl groups.

${ }^{1} \mathrm{H}$ NMR spectrum was registered by the spectrometer Bruker AM-300 (300 MHz) in $\mathrm{CDCl}_{3}$ using TMS as the internal standard. ${ }^{1} \mathrm{HNMR}$ spectrum is in agreement with HTMC structure. The spectrum shows signals at 1.38, 1.82, 1.82, 1.84, 1.91, $2.01,2.09,2.15,2.40,3.55,4.27$ and $4.90 \mathrm{ppm}$. Hydroxyethyl fragment protons are recorded at 3.55 and $4.27 \mathrm{ppm}$ as two triplets; and at $4.90 \mathrm{ppm}$ as a singlet. Six protons of cyclohexene fragment give four doublet signals at $1.84,1.91,2.01,2.09,2.15$ and $2.40 \mathrm{ppm}$. Methyl groups of a cycle in 3,4 positions resonate as two singlets at 1.82 and $1.82 \mathrm{ppm}$ and in methyl group of 1 position resonates as a singlet at $1.38 \mathrm{ppm}$.

${ }^{13} \mathrm{C}$ NMR spectrum was registered by the spectrometer (50 MHz) in $\mathrm{CDCl}_{3}$ using TMS as the internal standard. ${ }^{13} \mathrm{C}$ NMR spectrum is in agreement with HTMC structure. The carbons in the cycle are recorded at $121.2,121.9,41.2,40.8,27.0$ and $42.5 \mathrm{ppm}$. Two peaks at 121.2 and $121.9 \mathrm{ppm}$ are due to carbons of the carbon-carbon double bond in the cycle. Three peaks at $42.5,41.2$ and $40.8 \mathrm{ppm}$ and one peak at $27.0 \mathrm{ppm}$ are due to carbons of the $\mathrm{C}-\mathrm{C}$ bonds in the cycle. Peaks corresponding to carbons adjacent to the $\mathrm{C}=\mathrm{O}$ and $\mathrm{C}-\mathrm{O}-\mathrm{C}$ bonds are recorded at $175.9 \mathrm{ppm}$ (carboxyl group) and 52.1 and $64.1 \mathrm{ppm}$ (carbons in hydroxyethyl fragment). Three peaks at 21.6, 19.1 and $18.8 \mathrm{ppm}$ are related to the methyl groups.

\section{Conclusions}

Kinetics of the initial stages of the interaction between HEMA and DMB was investigated. Kinetic data indicated the synchronous cyclization process. The optimal conditions of the cyclization process have been empirically determined as follows: the temperature of $433 \mathrm{~K}$ and the molar ratio DMB:HEMA of 1.5:1. These conditions provide a satisfactory rate of cycloaddition reaction between DMB and HEMA and the HTMC yield reaches $87 \%$ at the output of $104 \mathrm{~g} /(1 \cdot \mathrm{h})$. The acceleration of the reaction with an increase in the depth of the process can be explained by matrix or cellular effects. The structure of the prepared product was confirmed by the refractometric analysis and ${ }^{1} \mathrm{H} ~ \mathrm{NMR},{ }^{13} \mathrm{C}$ NMR and IR spectroscopies. 


\section{REFERENCES}

1. Kostiv I., Dzeryn O., Malynovskyi Yu. Establishing optimal conditions for catalytic obtaining of allyl-1,3,4-trimethylcyclohex3-encarboxylate // East. Eur. J. Enterprise Technol. - 2017. Vol.6. - P.17-25.

2. Asymmetric synthesis of active pharmaceutical ingredients / V. Farina, J.T. Reeves, C.H. Senanayake, J.J. Song // Chem. Rev. - 2006. - Vol.106. - P.2734-2793.

3. Synthesis of 2,4-dimethyl-cyclohex-3-ene carboxaldehyde derivatives with olfactory properties / Monnier-Benoit P., Jabin I., Jaubert J.-N., Netchitailo P., Goyau B. // C. R. Chim. 2007. - Vol.10. - P.259-267.

4. Zweifel G.S., Nantz M.H., Somfai P. Modern organic synthesis. An introduction. - John Wiley \& Sons, Inc., 2017. $405 \mathrm{p}$.

5. Smets J., Steenwinckel P. Benefit agent delivery compositions. Patent US no. 0200359A1. - 2008.

6. Synthesis and structure of nitrocyclohexenylcarboxylates / N.A. Anisimova, A.A. Kuzhaeva, G.A. Berkova, V.M. Berestovitskaya // Russ. J. Gen. Chem. - 2011. - Vol.81. - P.1845-1852.

7. Optimization of 2,3-dimethylbuta-1,3-diene and 2-hydroxyethyl methacrylate cyclization reaction conditions / Kostiv I., Polyuzhin I., Vytrykush N., Marshalok G., Yatchyshyn J. // Chem. Chem. Technol. - 2014. - Vol.8. - P.35-40.

8. Optimization of synthesis conditions of 2,3-dimethylbutadiene / I.S. Polevaya, M.D. Fedevich, I.P. Polyuzhin, O.I. Marshalok // Russ. J. Appl. Chem. - 2011. - Vol.84. - P.261-265.

9. Synthesis of 1,3,4-trimethylcyclohex-3-en-1-carboxylic acid allyl ester / Polevaya I.S., Karpyak N.M., Fedevich M.D., Marshalok O.I., Pyrig I.J. // Russ. J. Appl. Chem. - 2012. Vol.85. - P.164-166.

10. Kinetics of allyl-1,3,4-trimethylcyclo-hex-3encarboxylate obtaining / I. Polyova, G. Marshalok, J. Yatchyshyn, I. Polyuzhin. // Chem. Chem. Technol. - 2012. - Vol.6. P.119-122.

11. Optimization of the production of methyl $1,3,4$ trimethylcyclohex-3-ene-1-carboxylate obtaining / Marshalok H., Kostiv I., Polyuzhin I., Marshalok O., Vytrykush N. // Przemysl Chemiczny. - 2016. - Vol.95. - No. 4. - P.745-750.

12. Gast L.E., Bell E.W., Teeter H.M. Reactions of conjugated fatty acids. III. Kinetics of the Diels-Alder reaction // J. Am. Oil Chem. Soc. - 1956. - Vol.33. - P.278-281.

13. Шмид Р., Сапунов В. Неформальная кинетика. М.: Мир, 1985. - 264 р.

\section{ВСТАНОВЛЕННЯ ОПТИМАЛЬНИХ УМОВ ОДЕРЖАННЯ 2-ГІДРОКСИЕТИЛ-1,3,4- ТРИМЕТИЛЦИКЛОГЕКС-3-КАРБОКСИЛАТУ}

\section{I.C. Костів, Р.І. Гаврилів}

Новий 2-гідроксиетил-1,3,4-триметилциклогекс-3-енкарбоксилат (НТМС) був синтезований за реакцією ДільсаАльдера. Досліджено вплив температури, молярного співвідношення реагентів на вихід цільового продукту. Вивчено кінетику реакції циклоприєднання 2,3-диметилбуту-1,3-дієну (ДМБ) та 2 гідроксиетилметакрилату (ГЕМА) за реакцією ДільсаАльдера. Визначені константи швидкості реакції та активаційні параметри реакиії. Досліджено вплив температури, молярного співвідношення реагентів на вихід цільового продукту. При збільшенні температури від 403 К до 433 K, вихід 2-гідроксиетил-1,3,4-триметилииклогекс-3-карбоксилату (ГТМК) збільшується з 76\% до 87\%. 3 подальшим підвищенням температури ДМБ кипить і ГЕМА залишається у рідкому стані, відповідно вихід вихідного продукту суттєво не зростає. Збільшення надлишку ДМБ:ГЕМА від 1:1 до 2,5:1 дозволяє збільшити вихід ГТМК з $83 \%$ до 87\%. Встановлені оптимальні умови одержання 2-гідроксиетил-1,3,4-триметилииклогекс-3карбоксилату: температура $433 \mathrm{~K}$ і молярне співвідношення реагентів ДМБ:ГЕМА=1,5:1; за иих умов вихід ГТМК становить $87 \%$ при продуктивності 104 г/(лггод). На основі одержаних констант швидкості реакції та параметрів активаціі [4+2]-циклоприєднання 2,3-диметилбута-1,3-дієну та 2-гідроксиетилметакрилату було встановлено, що досліджувана реакція підпорядковується кінетичному рівнянню другого порядку. Кінетичні дані вказують на процес синхронної циклізації. Прискорення реакцї̈ зі збільшенням глибини процесу може бути пояснено матричним або клітинним ефектами.

Ключові слова: 2,3-диметилбутадієн, 2 -гідроксиетилметакрилат, 2 -гідроксиетил-1,3,4триметилциклогекс-3-карбоксилат, циклоприєднання, циклогексенкарбоксилати. 


\section{DETERMINATION OF OPTIMAL CONDITIONS FOR PREPARATION OF 2-HYDROXYETHYL-1,3,4- TRIMETHYLCYCLOHEX-3-ENCARBOXYLATE}

\section{I.S. Kostiv *, R.I. Havryliv}

Lviv Polytechnic National University, Lviv, Ukraine

*e-mail: kostiv.irina@gmail.com

2-Hydroxyethyl-1,3,4-trimethylcyclohex-3-encarboxylate (HTMC) was synthesized by the reaction of Diels-Alder. The influence of temperature and molar ratio of reagents on the yield of the end product was investigated. The kinetics of the cycloaddition reaction between 2,3-dimethylbuta-1,3-diene (DMB) and 2-hydroxyethylmethacrylate (HEMA) was studied. The reaction rate constants and the activation parameters of the reaction were determined. It was stated that the yield of HTMC increases from $76 \%$ to $87 \%$ when the temperature increases from $403 \mathrm{~K}$ to $433 \mathrm{~K}$, respectively. With a further increase in the temperature, DMB boils and HEMA remains in a liquid state, therefore, the yield of the end product does not increase appreciably. An increase in the excess of DMB:HEMA from 1:1 to 2.5:1 allows increasing the yield of HTMC from $83 \%$ to $87 \%$. The optimal conditions for the HTMC production have been determined as follows: the temperature of $433 \mathrm{~K}$ and the molar ratio of reagents DMB:HEMA=1.5:1; the yield of $H T M C$ reaches $87 \%$ at the output of $104 \mathrm{~g} /(\mathrm{l} \cdot \mathrm{h})$ under these conditions. On the basis of the obtained reaction rate constants and the activation parameters of the [4+2]-cyclic addition of 2,3-dimethylbuta-1,3diene and 2-hydroxyethylmethacrylate, we found out that the reaction under study obeys the second-order kinetic equation. The kinetic data indicated the synchronous cyclization process. The acceleration of the reaction with an increase in the depth of the process can be explained by matrix or cellular effects.

Keywords: 2,3-dimethylbutadiene; 2-hydroxyethylmethacrylate; 2-hydroxyethyl-1,3,4-trimethylcyclohex-3-encarboxylate; cycloaddition reaction; cyclohexencarboxylates.

\section{REFERENCES}

1. Kostiv I., Dzeryn O., Malynovskyi Yu. Establishing optimal conditions for catalytic obtaining of allyl-1,3,4trimethylcyclohex-3-encarboxylate. Eastern-European Journal of Enterprise Technologies, 2017, vol. 6, pp. 17-25.

2. Farina V., Reeves J.T., Senanayake C.H., Song J.J. Asymmetric synthesis of active pharmaceutical ingredients. Chemical Reviews, 2006, vol. 106, pp. 2734-2793.

3. Monnier-Benoit P., Jabin I., Jaubert J.-N., Netchitailo P., Goyau B. Synthesis of 2,4-dimethyl-cyclohex-3-ene carboxaldehyde derivatives with olfactory properties. Comptes Rendus Chimie, 2007, vol. 10, pp. 259-267.

4. Zweifel G.S., Nantz M.H., Somfai P., Modern organic synthesis. An introduction. John Wiley \& Sons, Inc., 2017. 405 p.

5. Smets J., Steenwinckel P., Benefit agent delivery compositions. Patent US, no. 0200359A1, 2008.

6. Anisimova N.A., Kuzhaeva A.A., Berkova G.A., Berestovitskaya V.M. Synthesis and structure of nitrocyclohexenylcarboxylates. Russian Journal of General Chemistry, 2011, vol. 81, pp. 1845-1852.

7. Kostiv I., Polyuzhin I., Vytrykush N., Marshalok G., Yatchyshyn J. Optimization of 2,3-dimethylbuta-1,3-diene and 2-hydroxyethyl methacrylate cyclization reaction conditions. Chemistry \& Chemical Technology, 2014, vol. 8, pp. 35-40.

8. Polevaya I.S., Fedevich M.D., Polyuzhin I.P., Marshalok O.I. Optimization of synthesis conditions of 2,3-dimethylbutadiene. Russian Journal of Applied Chemistry, 2011, vol. 84 , pp. 261-265.

9. Polevaya I.S., Karpyak N.M., Fedevich M.D., Marshalok O.I., Pyrig I.J. Synthesis of 1,3,4-trimethylcyclohex3-en-1-carboxylic acid allyl ester. Russian Journal of Applied Chemistry, 2012, vol. 85, pp. 164-166.

10. Polyova I., Marshalok G., Yatchyshyn J., Polyuzhin I. Kinetics of allyl-1,3,4-trimethylcyclo-hex-3-encarboxylate obtaining. Chemistry \& Chemical Technology, 2012, vol. 6, pp. 119-122.

11. Marshalok H., Kostiv I., Polyuzhin I., Marshalok O., Vytrykush N. Optimization of the production of methyl 1,3,4-trimethylcyclohex-3-ene-1-carboxylate obtaining. Przemysl Chemiczny, 2016, vol. 95, no. 4, pp. 745-750.

12. Gast L.E., Bell E.W., Teeter H.M. Reactions of conjugated fatty acids. III. Kinetics of the Diels-Alder reaction. Journal of the American Oil Chemists Society, 1956, vol. 33, pp. 278-281.

13. Shmid R., Sapunov V., Neformalnaya kinetika [Nonformal kinetics]. Mir, Moscow, 1985. 264 p. (in Russian). 